\title{
Primary microglia maintain capacity to function despite internalisation and intracellular loading with carbon nanotubes
}

Dol:

10.1039/C7NH00055C

\section{Document Version}

Accepted author manuscript

Link to publication record in Manchester Research Explorer

Citation for published version (APA):

Bussy, C., Bianco, A., Prato, M., \& Kostarelos, K. (2017). Primary microglia maintain capacity to function despite internalisation and intracellular loading with carbon nanotubes. Nanoscale Horizons, 2.

https://doi.org/10.1039/C7NH00055C

\section{Published in:}

Nanoscale Horizons

\section{Citing this paper}

Please note that where the full-text provided on Manchester Research Explorer is the Author Accepted Manuscript or Proof version this may differ from the final Published version. If citing, it is advised that you check and use the publisher's definitive version.

\section{General rights}

Copyright and moral rights for the publications made accessible in the Research Explorer are retained by the authors and/or other copyright owners and it is a condition of accessing publications that users recognise and abide by the legal requirements associated with these rights.

\section{Takedown policy}

If you believe that this document breaches copyright please refer to the University of Manchester's Takedown Procedures [http://man.ac.uk/04Y6Bo] or contact uml.scholarlycommunications@manchester.ac.uk providing relevant details, so we can investigate your claim.

\section{OPEN ACCESS}




\section{Accepted Manuscript}

This article can be cited before page numbers have been issued, to do this please use: C. bussy, A.

Bianco, M. Prato and K. Kostarelos, Nanoscale Horiz., 2017, DOI: 10.1039/C7NH00055C.

\section{Nanoscale Horizons}
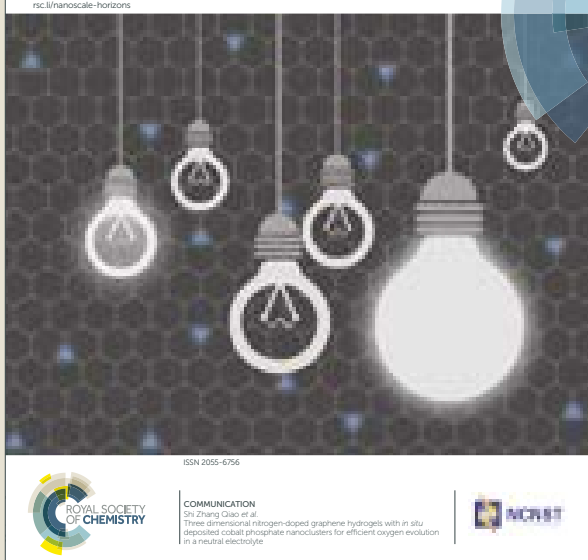

[J nenst
This is an Accepted Manuscript, which has been through the Royal Society of Chemistry peer review process and has been accepted for publication.

Accepted Manuscripts are published online shortly after acceptance, before technical editing, formatting and proof reading. Using this free service, authors can make their results available to the community, in citable form, before we publish the edited article. We will replace this Accepted Manuscript with the edited and formatted Advance Article as soon as it is available.

You can find more information about Accepted Manuscripts in the author guidelines.

Please note that technical editing may introduce minor changes to the text and/or graphics, which may alter content. The journal's standard Terms \& Conditions and the ethical guidelines, outlined in our author and reviewer resource centre, still apply. In no event shall the Royal Society of Chemistry be held responsible for any errors or omissions in this Accepted Manuscript or any consequences arising from the use of any information it contains. 
1

2 Primary microglia maintain capacity to function despite

3 internalisation and intracellular loading with carbon nanotubes

4

5

6

7

8

10

11

12

13

14

15

16

17

18

19

20

21

22

23

24

25

26

27

28

29

30

31

32

33

34

35

36

37

38

39

40

41

42

43

44

45

46

47

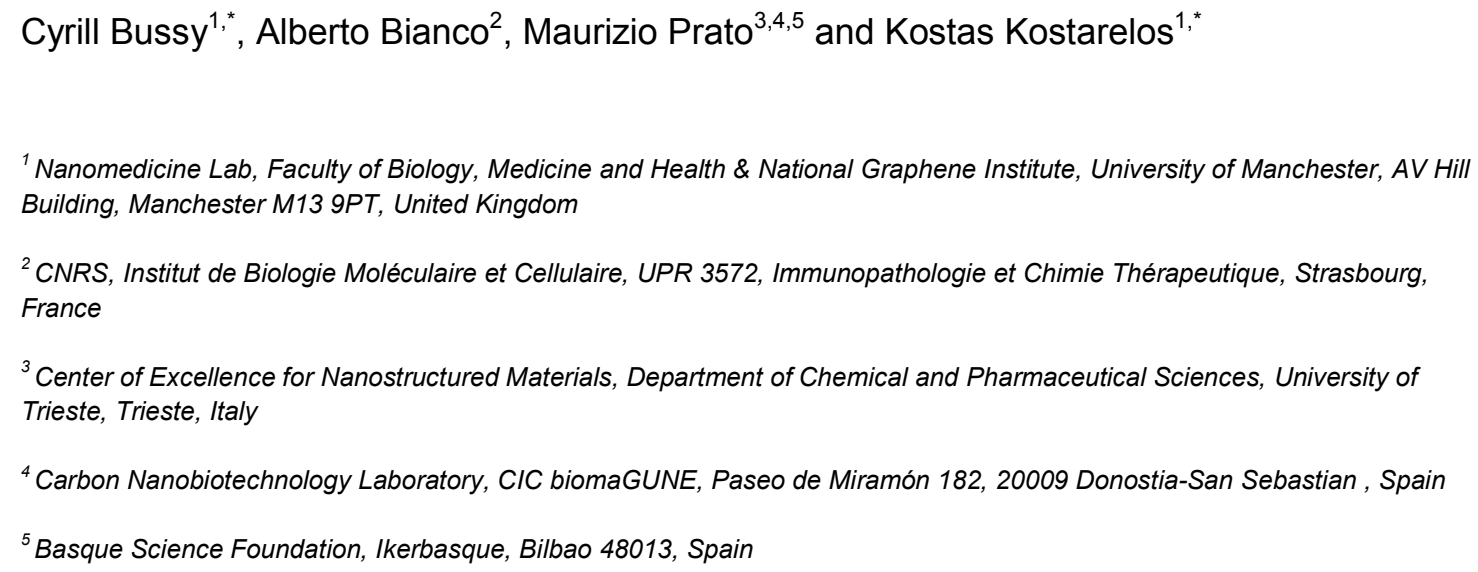




\section{Abstract}

2
Biomedical applications of functionalised carbon nanotubes ( $f$-CNTs) for imaging as well as drug or gene delivery in the brain have recently gained interest. Several studies have demonstrated the potential of $f$-CNTs to offer treatment options for neurological conditions with success. However, there is also evidence that $f$-CNTs accumulate preferentially within microglial cells when introduced in the brain. Considering the key immunologic role of these cells in the brain and the limited knowledge regarding the interaction of CNTs with microglial cells, it is imperative to understand whether accumulation of CNTs in microglial cells can alter their physiological functions or trigger pro-inflammatory signalling. The aim of the present study was to investigate the basic physiological functions of isolated primary microglial cells over time, following their exposure to multi-walled carbon nanotubes functionalized via different surface chemistries. We rationalized that some chemical strategies may be more deleterious for microglial cell functions than others. We used rat primary microglial cells that can be maintained in cell culture for a long period of time without undergoing cell division. Cell viability, phagocytosis, migration, pro-inflammatory factor release were studied over one month, following a single exposure to a non-cytotoxic concentration of three different $f$-CNTs (carboxylated, aminated and both carboxylated and aminated). We show that $f$-CNTs do not induce inflammation and are not affecting basic functions of microglial cells under these conditions. Importantly, this was the case from day 1 to day 28 post-exposure, even though microglial cells had internalized $f$-CNTs in subcellular compartments and retained the nanotube load in their cytoplasm over time.

\section{Key words}

nanomedicine; brain; biocompatibility; central nervous system; phagocytosis; neurotoxicity; nanotoxicology 


\section{Introduction}

In recent years, numerous nanomaterials have been utilised in an attempt to overcome the great challenge of drug delivery to the central nervous system ${ }^{1-3}$. Among them, carbon nanotubes (CNTs) have lately shown great promise ${ }^{4}$ due to their inherent properties, but also a unique ability to cross cellular barriers ${ }^{5}$. For instance, acetylcholine adsorbed onto single-walled CNTs (SWNTs) was efficiently delivered to cells in a kainic acid induced Alzheimer's Disease (AD) mouse model ${ }^{6}$. Amine functionalized multi-walled CNTs (MWNTs) have also been used successfully to deliver Caspase 3 siRNA into neurons with the aim to reduce the ischemic injuries in the motor cortex of an endothelin- 1 induced stroke model ${ }^{7}$. Similarly, amine functionalized SWNTs were injected in mouse brain ventricles in order to decrease the effects of ischemia and inflammation in an artery occlusion model of stroke ${ }^{8}$. The SWNT treated animals showed better histopathological and behavioural profiles after injury, indicating that aminated SWNTs could achieve a neuroprotective effect even without carrying any therapeutic agent. More recently, PEG-SWCNTs have also been proposed as solutions to alleviate glutamate excitotoxicity of neurons by increasing astrocytic glutamate uptake ${ }^{9}$.

Once localised in the brain parenchyma, knowledge of the fate and biological effects of those functionalised nanomaterials remains however limited. This raises the need for a better understanding of the interactions of carbon nanomaterials with the different cell subpopulations in the central nervous system (CNS). While neurons might be a preferred target for therapeutic purposes, nanomaterial in the brain parenchyma are likely to interact with other cell types including the resident macrophages of the brain, namely the microglial cells. Even in the case of nanoscale vectors bearing neuron-targeting moieties, microglial cells have indeed been shown to be the cell type in which a significant fraction of the nanomaterials were accumulating ${ }^{10}$. Considering that microglial cells are the main cellular component of the immune system in the brain, any nanomaterial that is intended for intracerebral applications should therefore have a controlled and well-understood interaction with those cells.

In terms of our current understanding of CNT-microglia interactions, microglial cells have been reported to play a major role in internalising functionalised CNTs ( $f$-CNTs) in comparison to other cell types following stereotactic administration of $f$-CNT in the cortex of mice $^{7,11,12}$. Similar results were obtained in vitro in mixed cell culture of primary glial cells, whereby microglial cells were displaying higher uptake of functionalised MWNTs ( $f$-MWNTs) compared to astrocytes ${ }^{13}$. Interestingly, following internalisation in microglial cells, we have observed the partial degradation of $f$-MWNTs over time, both in vivo over 14 days ${ }^{12}$ and in 
1 vitro in a primary cell culture model up to 90 days ${ }^{14,15}$. Alteration within $24 \mathrm{~h}$ of the graphitic

structure of $f$-MWNTs in the immortalised N9 microglial cell line offered independent validation ${ }^{16}$

These degradation results suggested that despite the internalisation of $f$-CNTs, microglial cells were able to maintain one of their primary functions over time: their ability to degrade foreign materials ${ }^{12,14,17}$. In contrast, MWNTs dispersed in horse serum were shown in vitro to alter microglial functions such as migration and phagocytosis, and also cell division in BV2 immortalised microglial cell model after their internalisation ${ }^{18}$. The main hypothesis to explain these alterations was the direct interaction of MWNTs with the cytoskeleton of BV2 cells leading to an impairment of all cytoskeleton related functions including migration and phagocytosis. The present study was therefore designed to interrogate the impact of internalisation and retention of $f$-CNTs in microglial cells on their capacity to perform normal cellular and macrophage-specific functions, other than their degradation ability that was previously demonstrated ${ }^{14,15}$.

In addition, using different chemical derivatives of $f$-CNTs, surface properties have been revealed as essential determinants that could modulate both CNT-microglia interaction and bioreactivity of CNTs towards microglial cells. Firstly, the type of surface functionalisation was demonstrated to influence the uptake ${ }^{19}$. Phosphatidyl-serine coated SWNTs were engulfed by primary rat microglia while phosphatidyl-choline coated and non-coated SWNTs were not. Similarly, microglial cells were shown to be very efficient at internalising oxidised MWNTs but were not fully able to break apart agglomerates of pristine MWNTs and to internalise them ${ }^{16}$. Secondly, the type of functionalisation was shown to modulate the response of microglial cells. While both pristine and oxidised MWNTs were not altering cell viability, pro-inflammatory cytokine release or nitric oxide (NO) production, a significant increase of reactive oxygen species production was measured after exposure to pristine MWNTs, suggesting possible impact on cell viability at long term ${ }^{16}$. Accordingly, using an in vivo cortical stereotactic injection model, brain cells and microglial ones in particular were reported to differently respond to $f$-CNTs exposure depending on the surface functionalisation of the materials injected ${ }^{11}$. Functionalisation was not only impacting the localisation and distribution pattern of the injected materials within the brain, but also modulating the inflammatory profile of the different $f$-CNTs. Oxidised MWNTs were shown to induce and sustain a microglial cell mediated inflammatory response while aminated MWNTs were only transiently inducing inflammation.

Taken together, these studies demonstrate the major importance of material surface properties and in particular the type of surface functionalisation on the biological outcomes of

37 the material-cell interaction. Moreover, ability by CNTs to induce inflammation and impact on 
1 microglial cell physiological functions are two key endpoints that should be systematically

investigated and correlated to the surface chemistry of the materials in order to determine the best biocompatibility profile for putative CNT-based brain delivery systems.

The objectives of the present study were therefore to investigate whether microglial cell functions can be affected by the internalisation of $f$-CNTs, whether varying the surface chemistry of $f$-CNTs can modulate the cell response, and whether the impact of these different $f$-CNTs on microglial cell functions may evolve over time. Oxidation of CNTs has been shown to increase the bioreactivity of those materials for macrophages ${ }^{11,20}$, we therefore hypothesised that the degree of oxidation/carboxylation is determinant to modulate the biological responses and can affect microglial cell functions while not inducing cell death.

To assess this hypothesis we selected three MWNTs with different carboxylation degree (purely carboxylated, purely aminated and one type baring both carboxyl and amine groups).

We additionally developed a primary rat microglial cell model that demonstrated a long lifespan in vitro without undergoing division to monitor over time the evolution of microglial cell functions after internalisation of the materials. Cytotoxicity, phagocytosis, migration and pro-inflammatory mediator release were studied at different time points and up to 28 days following a single exposure to a non-cytotoxic concentration of the three selected $f$-CNTs. We report that $f$-MWNTs irrespective of their chemical functionalisation did not affect microglial cell viability under our conditions and did not induce release of pro-inflammatory mediators at any time points. Moreover, despite an important perinuclear internalisation of materials, microglial cells maintained their abilities to phagocytose and to migrate. Interestingly, oxidation of MWNTs stimulated the migration ability of microglial cells that have engulfed those CNTs in comparison to aminated MWNT laden cells.

\section{Results and Discussion}

Chemical structure and characterisation of MWNT suspension. The selection of MWCNTs over other CNT types such as single walled- or double walled- CNTs was motivated by our previous works on the interactions of $f$-MWNTs with brain cells ${ }^{7,11-13,21}$ and microglial cells in particular ${ }^{14,15}$. We have also demonstrated that these functionalised nanomaterials can be used as delivery platforms for drugs ${ }^{22}$, genes ${ }^{7,23}$ or contrast agents ${ }^{24}$. The type of chemical functionalisation was previously identified by some of us as a major determinant of the in vivo ability of $f$-MWNTs to induce inflammation in the brain ${ }^{11}$. Comparing two types of $f$-MWNTs, one that has been pre-oxidised and then aminated with one that has been aminated only, oxidation/carboxylation was revealed as causing inflammation, even though the effects of MWNTs bearing only carboxyl groups (i.e. negative 
1 charges) were not directly investigated. Here, three chemically functionalised MWNTs with different level of oxidation were synthesised from the same starting materials in order to limit batch-to-batch variations. Their chemical structure is presented in Figure 1 and they include: (i) carboxylated MWNTs (ox-MWNTs) prepared by treatment of the starting materials in strong acid conditions ${ }^{25}$; (ii) amino-functionalized oxidised MWNTs (ox-MWNT- $\mathrm{NH}_{3}{ }^{+}$) prepared by 1,3 dipolar-cycloaddition reaction after an initial oxidation as described previously ${ }^{26}$; and (iii) amino-functionalized MWNTs (MWNT- $\mathrm{NH}_{3}{ }^{+}$) prepared following the 1,3 dipolar-cycloaddition reaction on the starting materials as described previously ${ }^{27,28}$. Length of $\mathrm{MWNT}-\mathrm{NH}_{3}{ }^{+}$remained similar to the one of the starting materials (between 0.5-2 $\mu \mathrm{m}$ ) while it was reduced for materials undergoing oxidation (shorten to $300-400 \mathrm{~nm}$ for ox-MWNT and ox-MWNT- $\mathrm{NH}_{3}{ }^{+}$). Suspensions of MWNTs were prepared by hydrating dry powder with a $5 \%$ dextrose water solution, which was then sonicated until MWNTs reached a good dispersion (about $40 \mathrm{~min}$ ). It was essential to achieve a dispersion of similar quality for the three materials to prevent non-intrinsic differences amongst them. Difference in dispersion quality is indeed known to induce differences in biological responses especially inflammation 29, 30 and could therefore lead to biases in experiment outcomes and misinterpretation in regards to the role of chemical functionalisations. To assess the stability of the 3 MWNT dispersions in $5 \%$ dextrose water solution, analysis of the absorbance (used as an index of dispersion, well dispersed materials absorbing more than agglomerated ones) was performed at $0 \mathrm{~h}$ and $24 \mathrm{~h}$ (Figure S1, first column). Despite the intrinsic differences between the 3 materials (highest absorbance: ox-MWNT-NH ${ }_{3}{ }^{+}>\mathrm{MWNT}^{-\mathrm{NH}_{3}}{ }^{+}>$ox-MWNT), no difference between the absorbances at $0 \mathrm{~h}$ and $24 \mathrm{~h}$ could be observed for any materials. All 3 materials were stable over $24 \mathrm{~h}$ in $5 \%$ dextrose. Similar stability results over $24 \mathrm{~h}$ were observed when the materials initially suspended in $5 \%$ dextrose were diluted in cell culture medium supplemented with 12\% FBS (Figure S1, second column). However, when materials initially suspended in $5 \%$ dextrose were then diluted in cell culture medium without FBS, the UV-Vis spectrometric analysis evidenced a clear sedimentation for all 3 materials, regardless of their surface chemistries (Figure S1, third column). These results suggested that MWNT suspensions were not stable in cell culture medium without the addition of FBS, and would sediment at the bottom of the cell culture wells under these conditions, increasing the potential of materials to interact with the monolayer of cells. In contrast the addition of FBS would not be favourable to interaction with cells as most materials would stay in suspension, above the cell monolayer.

Functionalised nanotubes had no effect on microglial cell viability. Microglial cells were revealed as the main cell population in which $f$-MWNTs are accumulating when infused in the brain parenchyma ${ }^{7,11,12}$, or when exposing mixed glial cells cultures (containing mainly 
1 astrocytes and microglial cells) ${ }^{13,14}$. However, the impact of this preferential accumulation remains elusive and contradictory in the literature. We therefore first questioned whether the exposure to different $f$-MWNTs using a non-overload concentration will affect the viability of microglial cells over time. To answer that question, a model of primary microglial cell cultures that can be maintained over long period of time without cell division was used. It was rationalised that once in the brain parenchyma, $f$-MWNTs will diffuse throughout the tissue as observed for other nanomaterials ${ }^{31}$ and therefore each microglial cell will likely be exposed to a limited amount of nanotubes. To ensure that microglial cells interacted with the MWNTs, we favoured the CNT sedimentation by exposing cells to MWNTs in a serum free environment for $2 \mathrm{~h}$, following which the cell culture medium was supplemented with $12 \%$ FBS. Following this single exposure to a unique dose of $10 \mu \mathrm{g} / \mathrm{mL}$, we used a modified LDH assay developed in our lab ${ }^{32}$ to assess the impact of $f$-MWNTs on microglial cell viability at 1, 7, 14 and 28 days after the initial exposure (Figure 2). No effect on the viability of exposed microglial cells compared to untreated cells was observed irrespective of $f$-MWNTs used or time after exposure. However, a statistically significant difference was observed at day 1 for ox-MWNT- $\mathrm{NH}_{3}{ }^{+}$treated cells when compared to their respective control (untreated cells). This could be ascribed to the primary nature of the cell cultures used here (more dying cells in untreated cells than in ox-MWNT- $\mathrm{NH}_{3}{ }^{+}$treated cells) ${ }^{14}$ or to a stimulation of viability as primary microglial cells preserve the ability to divide under stimulatory conditions ${ }^{33}$. Further investigations will be needed to address this question. Overall, these results suggested that microglial cells are tolerant to $f$-MWNTs exposure under the conditions used here, and that this tolerance is not dependent on the type of chemical functionalisation for this concentration. These results were in agreement with previous observations of a dose dependent cytotoxicity appearing after $24 \mathrm{~h}$ above $10 \mu \mathrm{g} / \mathrm{mL}^{13}$.

Primary microglial cells internalised and kept nanotubes over time. CNTs found primarily free in the cytoplasm were reported to reduce proliferation and induce apoptosis in BV2 cells, an immortalised model of microglial cells ${ }^{18}$. In order to explain the difference between this study and the viability results of the present study (Figure 2), optical microscopy was used to investigate the internalisation pattern and evolution of CNT loading over time (Figure 3a, S2 and S3). For all three $f$-MWNTs and irrespective of the time point considered, the distribution of nanotubes observed as black material in bright-field mode (Figure S2 and S3) was characteristic, with an accumulation of materials around the nucleus (perinuclear region), absence of black material in the nucleus, and no apparent accumulation in the cytoplasm periphery close to the cell boundaries (Figure S3). No obvious difference in 
1 that exocytosis was limited. In addition, using immunocytochemistry (anti-CD68), a singular pattern of CD68 immunolabelling was observed, with black materials appearing as entrapped in vesicles positive for CD68 immunoreactivity (Figure S4). The vesicular pattern was enhanced and contrasted by the black materials contained within the CD68 positive vesicles. CD68 is predominantly an intracellular glycosylated transmembrane protein with minimal surface expression in unactivated macrophages ${ }^{34}$. The perinuclear position of CNT accumulation, the absence of diffuse CNT-related black signal across the cytoplasm, and the vesicular pattern of CD68 immunoreactivity suggested a vesicular accumulation of $f$-MWNTs.

In order to confirm that the punctuated black halo around the nucleus (Figure S5b) was indeed due to localised accumulation of carbon nanotubes, Raman spectroscopy analysis was performed at a single cell level and in different places of the considered cell (Figure $3 \mathrm{~b}$ ). The characteristic peaks at $1360 \mathrm{~cm}^{-1}$ (D band), $1585 \mathrm{~cm}^{-1}$ ( $\mathrm{G}$ band) and 1620 $\mathrm{cm}^{-1}$ ( $D^{\prime}$ band) were used to confirm the CNT nature of the accumulation ${ }^{35,36}$. Following exposure to $f$-CNTs, all three microglial cell cultures exhibited the specific Raman signature of MWNTs (i.e. D, G, D' bands) in the perinuclear region (Figure S5b). For each $f$-CNTs, the Raman profile found in cells (Figure $3 \mathbf{b}$ ) was similar to the Raman profile of the starting materials used to treat the cells (Figure S5a), confirming the adequacy and specificity of Raman fingerprints to characterise carbon nanomaterials. In addition, Raman signature of MWNTs was observed at each time points tested (i.e. 1, 7, 14 and 28 days), confirming the persisting perinuclear presence of $f$-CNTs in each case (Figure 3b). Taken together, these results show that the type of chemical functionalisation had no influence on the internalisation of $f$-MWNTs, their distribution within the cells, and their overtime retention in microglial cells. However, both endocytosis and exocytosis of $f$-MWNTs in primary microglial cells will need further investigations to fully describe the mechanisms and kinetic of processes at stake. In particular, further studies investigating the amount of materials internalised and maintained in cells over time for each $f$-MWNT considered will be important, as over time degradation in microglial cells in a surface chemistry dependent manner has been recently confirmed using two different methodological approaches ${ }^{14,15}$. Importantly, as mentioned above, the persistent retention of $f$-MWNTs over 28 days around the nucleus of microglial cells had no effect on viability, which demonstrated an absence of correlation between intracellular accumulation of materials and cytotoxicity under the considered conditions.

Uptake of $\boldsymbol{f}$-MWNTs did not induce pro-inflammatory reaction in microglial cells. Since internalisation of CNTs had no effect on microglial cells viability over time, it was then questioned whether the CNT uptake could induce the release of pro-inflammatory factors. The Griess assay was therefore used to measure the amount of NO released by MWNT 
1 exposed microglial cells at 1, 7, 14 and 28 days after the initial exposure (Figure 4). NO is one of the main markers for microglial cell activation and pro-inflammation induction, and is also a toxic agent for neurons ${ }^{17,37}$. A statistically significant release of NO compared to untreated cells was observed $24 \mathrm{~h}$ after the initial exposure to CNTs for all three $f$-MWNTs. However, this positive release of pro-inflammatory markers was largely limited in comparison to LPS stimulated microglial cells. At later time points, the release of NO became not significant compared to untreated cells and disappeared at 28 days. These data showed that $f$-MWNTs irrespective of their surface functionalisation have a limited ability to induce inflammation in vitro under the conditions used here, and that their internalisation and persistence in microglial cells over time did not lead to chronic pro-inflammatory reaction, as would have been expected if microglial cells were activated and inducing an immune response, as previously observed with other MWNTs ${ }^{16}$.

Uptake of $\boldsymbol{f}$-MWNTs did not alter internalisation or migration abilities. The presence of $f$ MWNTs inside microglial cells for 28 days did not seem to affect their viability or to induce an inflammatory reaction. The next question was then to know whether other basic physiological functions characteristic of resident macrophages would stay unimpaired by $f$-MWNT exposure and over-time persistence in cells.

Firstly, the internalisation ability of CNT-laden microglial cells was tested, using 0.5 $\mu \mathrm{m}$ fluorescently labelled polystyrene beads. It was rationalised that if the internalisation ability was maintained, the uptake of polystyrene beads for each microglial cell considered would be limited only by the amount of materials (i.e. CNTs) already inside these MWNTpreloaded cells. The internalisation of polystyrene beads inside microglia previously exposed to MWNTs was assessed over $8 \mathrm{~h}$ and compared to naïve microglial cells (i.e. non-exposed to MWNTs) and activated microglial cells (i.e. non-exposed to MWNTs but stimulated by LPS $(200 \mathrm{ng} / \mathrm{mL})$ ) (Figure 5 and S6). The internalisation assay was performed only at day 7 after exposure to CNTs because it was observed that engulfment of polystyrene beads was leading to acute cytotoxicity at later time points (14 and 28 days) for all cells, naïve microglial cells included. This was attributed to the age of the primary cells, which have been isolated from brain tissue about 1.5 months before day 14 time point. Similarly, the test was not performed at day 1 after exposure to MWNTs because the cells were exposed to MWNTs the day before and some free nanotubes might still be in the supernatant and would be in direct competition with the polystyrene beads for internalisation. At the earliest time point ( $1 \mathrm{~h}$ after the bead treatment), there was no major difference between groups, including untreated cells or LPS stimulated cells (Figure 5c and S6). While non-statistically significant, the amount of polystyrene beads (i.e. fluorescence) in microglial cells previously exposed to oxidised MWNTs (i.e. both ox-MWNT and ox-MWNT- $\mathrm{NH}_{3}{ }^{+}$) was however lower compared to 
1 untreated cells (Figure 5c and S6). After $2 \mathrm{~h}$, the LPS stimulation greatly enhanced the polystyrene beads internalisation compared to the other groups (Figure 5a and 5c). In addition, the internalisation of polystyrene beads was slightly higher for microglia exposed to

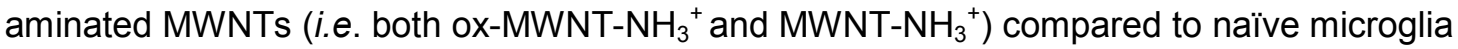
or microglia exposed to ox-MWNT. After $8 \mathrm{~h}$, there was no significant difference between the various groups suggesting that all groups of cells had reached their highest loading in polystyrene beads possible (Figure $\mathbf{5 b}$ and $\mathbf{5 c}$ ). It also suggested that despite their initial CNT loading, CNT-laden microglial cells were able to internalise polystyrene beads to the same extend as cells not pre-loaded with CNTs. These results showed that the internalisation ability of microglial cells was not perturbed by uptake of $f$-MWNTs, irrespective of the type of chemical functionalisation tested. These results also underlined the relative tolerance of cells to $f$-MWNTs exposure, especially when considering non-overload non-toxic doses (i.e. $10 \mu \mathrm{g} / \mathrm{mL}$ ).

The migration ability of CNT-laden microglial cells was then tested. Following the observation that unintended scratch on the plastic cell culture surface during the renewal of cell culture medium was inducing migration of microglial cells toward the scratch, a specific migration assay based on "scratch stimulated" migration was developed. The migration assay was performed at day 7,14 and 28 days after the initial exposure to one of the three $f$ MWNTs and compared to the results with naïve microglial cells and microglial cells stimulated with LPS (200 ng/mL) (Figure 6 and S7). The assay was not performed on the day following the exposure to CNTs as free CNTs might still be present in the supernatant and perturb the assay. Unexpectedly, migration of microglial cells stimulated by LPS was inhibited at all three time points tested compared to untreated cells (Figure S7 and 6). LPS is indeed known to stimulate migration and should have acted as a positive control/stimulator of migration ${ }^{38}$. It was previously reported that the amount of LPS used during an assay is a critical parameter that can influence the motility of primary microglial cells ${ }^{39}$. While low $(0.1$ $\mathrm{ng} / \mathrm{mL})$ or high (100 $\mathrm{ng} / \mathrm{mL})$ concentrations were shown to have no effect on promoting migration, $10 \mathrm{ng} / \mathrm{mL}$ was reported as the adjusted dose which induce higher migration compared to control cells. In our case, the reduce motility of microglial cells under LPS condition can possibly be explained by the deviation of normal macrophage functionalities toward an activation profile dedicated to pro-inflammatory factors secretion due to overload LPS dose (i.e. $200 \mathrm{ng} / \mathrm{mL}$ was used for both NO release and migration assay). This will require further investigations to fully understand the reason of this unusual behaviour of LPS stimulated microglial cells and confirming the optimal concentration of $10 \mathrm{ng} / \mathrm{mL}$ for promoting migration ${ }^{39}$.

As regards to $f$-MWNTs, a chemical functionalisation dependent modification of the microglial cell migration ability was observed (Figure 6). At any time point, microglial cells 
1 exposed to ox-MWNT had higher migration ability than cells exposed to aminated MWNTs

2 (i.e. both ox-MWNT- $\mathrm{NH}_{3}{ }^{+}$and MWNT- $\mathrm{NH}_{3}{ }^{+}$) with MWNTs bearing both chemical functions

3 (i.e. ox-MWNT- $\mathrm{NH}_{3}{ }^{+}$) in between ox-MWNT and $\mathrm{MWNT}^{-\mathrm{NH}_{3}}{ }^{+}$. At day 7 , microglial cells

4 exposed to ox-MWNT migrated to the same extend as untreated cells whereas microglial

5 cells exposed to aminated MWNTs (i.e. both ox-MWNT-NH ${ }_{3}{ }^{+}$and $\mathrm{MWNT}-\mathrm{NH}_{3}{ }^{+}$) moved less

6 than untreated cells. At day 14, surprisingly, microglial cells exposed to any type of MWNTs

7 migrated more than untreated cells. At day 28 , only microglial cells exposed to oxidised

8 MWNTs (i.e. both ox-MWNT and ox-MWNT-NH ${ }_{3}{ }^{+}$) migrated more than untreated cells or

9 cells exposed to MWNT- $\mathrm{NH}_{3}{ }^{+}$, which both show similar migration ability. These results showed that internalisation of $f$-MWNTs did not alter microglial cell migration ability and that exposure to (and uptake of) $f$-MWNTs can actually stimulate migration ability in a chemical

12 functionalisation dependent fashion. In contrast to amination, oxidation of MWNTs seemed to 13 stimulate the migration ability. Similar enhance migration ability in comparison to untreated cells has been recently observed when peritoneal macrophages were exposed to nano graphene oxide flakes and to a higher extend when exposed to nano graphene oxide functionalised with PEG groups ${ }^{40}$. In this study, enhanced cell migration was attributed to the activation of the cells towards a pro-inflammatory profile upon exposure to graphene oxide flakes. A correlation between enhanced cell migration and activation was not identified in the present study (Figure 4 and 6) and would therefore require further investigations to reveal the mechanism at the origin of the enhanced migration ability of cells exposed to oxidised MWNTs. exposure of primary microglial cells to different types of $f$-MWNTs was observed, despite the over-time persistence of the nanomaterials in the cytoplasm, in vesicles (Figure S4 and inset of Figure S5), and regardless of the type of surface functionalisation. These results are in agreement with other in vitro studies performed using the BV2 microglial cell line exposed to non-functionalised MWNTs, in which either cytotoxicity nor induction of expression of major inflammation markers were observed despite CNT internalisation at $48 \mathrm{~h}$ ${ }^{41}$. Similarly, no cytotoxicity or pro-inflammatory cytokine release or NO production were observed in vitro in the N9 microglial cell line exposed to oxidised MWNTs despite internalisation ${ }^{16}$. On the contrary, using similar MWNTs and similar surface functionalisation (ox-MWNT- $\mathrm{NH}_{3}{ }^{+}$and MWNT-NH${ }_{3}{ }^{+}$), in vivo cortical injection of $f$-MWNTs was demonstrated to induce a neuroinflammatory response that was surface chemical functionalisation dependent ${ }^{11}$. One month after injection, the degree of oxidation of the $f$-MWNTs was suggested to be a major factor driving the immune tissue response to explain the higher 
1 amount of CD11b positive (microglial cell marker) and GFAP positive (astrocyte marker) cells around the site of injection for animals injected with $f$-MWNTs compared to vehicle injected animals.

In contrast to previous reports, no effects due to interaction of $f$-MWNTs with the cytoskeleton were observed here. It was indeed previously speculate that if CNTs are free in the cytoplasm and interacting with the cytoskeleton, eventually forming bundles with microtubules and microfilaments, they could possibly rigidify cells and consequently reduce both migration and phagocytosis/internalisation abilities of the cells ${ }^{18}$. However, both internalisation and migration abilities were here found to be normal in $f$-MWNTs exposed microglial cells, despite a high internalisation of materials illustrated by a black halo around the nucleus region and confirmed to be made of CNTs by Raman spectroscopy. This suggested that $f$-MWNTs were likely not free in the cytoplasm but in vesicular compartments, which is in agreement with the microscopic results presented in Figure 3a, S2, S3, S4 and S5. Secondly, this also meant that although their cytoplasm were relatively congested with CNT loading, cells were still elastic enough to perform basic cytoskeleton-mediated functions and especially cell migration, one of the most important cell function in vivo for clearance of foreign materials ${ }^{17,37}$. This led us to believe that in vivo the tested materials would probably undergo brain tissue emigration through microglial cell-mediated drainage finishing in the lymphatic system without harming microglial cells. However, further studies are needed to address that specific hypothesis and to assess whether free f-MWNTs (not engulfed in any brain cells) would be able to use the brain solutes elimination system (i.e. glymphatic clearance system) ${ }^{42,43}$.

Theoretically, CNT-cytoskeleton interactions can also hamper the cytoskeleton dynamics required during cell division, and therefore modify the cell cycle, which would eventually lead to apoptosis. Using the dividing BV2 microglial cell model, MWNTs were indeed shown to induce apoptosis at the relatively low concentration levels of 0.6 and 6 $\mu \mathrm{g} / \mathrm{mL}$ ( $35 \%$ and $66 \%$, respectively) ${ }^{18}$. Induction of apoptotic pathway was also explained by cell cycle arrest due to CNT interactions with cytoskeleton molecules ${ }^{18,44}$. In contrast to these studies, no cell death at $10 \mu \mathrm{g} / \mathrm{mL}$ regardless of the time point considered was observed here. Seclusion of $f$-MWNT loading in vesicular compartments over time is likely the best explanation for the difference between the present results and previous reports. This will require complementary investigations on the subcellular fate of $f$-MWNTs, notably to confirm the nature of the vesicular compartmentalisation of the CNT content and its potential dynamics (endocytosis/exocytosis) over time. Moreover, a complete dose-response relationship correlated with the physicochemical features of the materials should be performed in order to identify the full extent of microglial tolerance to $f$-MWNTs and its 37 limitations. 
Degradation and clearance of cell debris and foreign materials are also a fundamental role of microglial cells for maintaining brain homeostasis ${ }^{17}$. After stereotactic administration of aminated MWNTs in the cortex of mice, resident microglial cells were reported to internalise and then alter the structural integrity of the injected materials ${ }^{12}$. Analysis of tissue sections via Raman spectroscopy and electron microscopy gave evidence of the initiation of a degradative process within two days following the injection. Similarly, it was shown that after $24 \mathrm{~h}$, the $\mathrm{N} 9$ microglial cells were able to alter the graphitic structure of oxidised MWNTs ${ }^{16}$. And finally, but more importantly using the same model as described in the present study (same primary cells, same $f$-MWNTs, same $10 \mu \mathrm{g} / \mathrm{mL}$ dose), primary microglial cells were showed to degrade $f$-MWNTs over time, irrespective of the surface functionalisation of MWNTs ${ }^{14,15}$. These results demonstrate that in addition to conserving their internalisation and migration abilities as reported here, microglial cells had preserved their degradation functions despite their CNT loading. Taken together, these results confirm that microglial cells exposed to $10 \mu \mathrm{g} / \mathrm{mL}$ of the $f$-MWNTs used here are still fully functional cells.

The agglomeration and colloidal properties of the three CNT suspensions were not found to be different (Figure S1). Similarly, variations in the surface chemical functionalisation were not found to be deterministic in the impact of the three CNTs apart from the migration ability that seemed to be stimulated by the two oxidised CNTs, in an oxidation degree dependent manner (ox-MWNT>> ox-MWNT- $\mathrm{NH}_{3}{ }^{+}$; Figure 6). But alongside surface chemical functionalisation and agglomeration, dimensions (both length and diameter) are important parameters for CNT biological impact ${ }^{45-48}$. In this respect, the type of CNTs (multi-walled rather than single-walled or double-walled) could also be important as dimensions together with agglomeration will highly differ between CNT types. Therefore, the present results obtained with MWNTs are likely to be different if SWNTs would have been used.

\section{Conclusion}

In summary, primary microglial cells when exposed to a low concentration of $f$-CNTs maintained their basic resident macrophage functions (phagocytosis/internalisation, migration, degradation) and did not initiate an inflammatory reaction despite a large internalisation of materials in cytoplasm vesicles. Considering the key role of microglial cells within the brain, the demonstration of the relative absence of bioreactivity of $f$-CNTs upon interaction with microglial cells is an important step towards their development as nanovectors for drug delivery purpose in the central nervous system. 


\title{
1 Experimental
}

2 Materials, MWNTs and preparation of MWNT suspensions for cell exposure. Chemicals and

3 solvents were obtained from Merck / Sigma-Aldrich (UK). Cell culture reagents (PBS, trypsin, foetal

4 bovine serum, DMEM:F12) were purchased from Gibco (ThermoScientific, UK). Multi-walled carbon

5 nanotubes (MWNT) were purchased from Nanostructured and Amorphous Materials Inc. (Houston,

6 TX, USA; Lot \# 1240XH, 95\%). The different chemical functionalisation of the MWNTs were performed

7 as previously reported ${ }^{25,27,28,32}$. The amount of $\mathrm{COOH}$ (on both ox-MWNT and ox-MWNT- $\mathrm{NH}_{3}{ }^{+}$) after

8 the oxidation reaction has been previously calculated using thermogravimetric analysis, corresponding

9 to $1.7 \mu \mathrm{mol} \cdot \mathrm{g}^{-149}$ while the amount of amino groups measured by Kaiser's test was $170 \mu \mathrm{mol} \cdot \mathrm{g}^{-1}$ for ox-

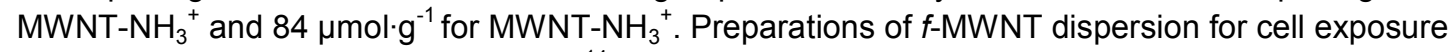
were performed as previously reported ${ }^{14}$.

\begin{abstract}
Stability of $f$-MWNT suspension in different media assessed by UV-Vis spectrophotometry. Suspension of the three $f$-MWNTs originally prepared in $5 \%$ dextrose water solution $(1 \mathrm{mg} / \mathrm{mL})$ were diluted to $10 \mu \mathrm{g} / \mathrm{mL}$ in $5 \%$ dextrose water solution, cell culture medium (DMEM:F12) supplemented with $12 \%$ FBS or cell culture medium (DMEM:F12) without FBS. Absorbance spectra were acquired at $0 \mathrm{~h}$ and $24 \mathrm{~h}$ after preparing the different $10 \mu \mathrm{g} / \mathrm{mL}$ suspensions using a Cary 50 Bio UV/Vis spectrophotometer (Varian Inc., Agilent Technologies, UK). For measurement, the prepared suspensions were transferred from a microtube $(0.5 \mathrm{~mL})$ to a $1 \mathrm{~mL}$ quartz cuvette with $1 \mathrm{~cm}$ path length. Measurements were performed at room temperature, using a dual beam mode with baseline correction based on $5 \%$ dextrose water solution, cell culture medium with $12 \%$ FBS or cell culture medium without FBS, as blank controls to create the baseline.
\end{abstract}

Primary microglial cell cultures and exposure to functionalised CNT. The preparation of primary microglial cell cultures were performed as previously reported ${ }^{14}$ and according to a previously described method, based on mild trypsinisation of mixed glial cell culture ${ }^{50}$ prepared from rat embryonic stratial extracts. Microglial cell cultures were then exposed for $2 \mathrm{~h}$ to a non-cytotoxic 10 $\mu \mathrm{g} / \mathrm{mL}$ CNT suspension prepared in serum free cell culture medium (DMEM:F12 medium). After $2 \mathrm{~h}$ incubation at $37^{\circ} \mathrm{C}$ without serum, the cell culture medium was completed with heat inactivated foetal bovine serum (12\%). After $24 \mathrm{~h}$ incubation at $37^{\circ} \mathrm{C}$, the supernatant containing CNTs was removed, cells were washed twice with pre-warmed PBS and then incubated with CNT free complete medium (DMEM:F12 with $12 \%$ serum) for 1, 7, 14 and 28 days (recovery periods). CNT-free complete medium was changed every 3 days.

Cell viability assess by modified LDH assay. Cell viability was assessed by a modified LDH assay as previously described ${ }^{32}$. The Promega Cytotox 96 @ Non-radioactive cytotoxicity assay (Promega, UK) was modified to avoid interference between CNTs and LDH. DMSO $10 \%$ was used as positive control of the assay. Microglial cell cultures were generated in 24 well plates. At the desired time points $(1,7,14$ and 28 days), cells were lysed with $10 \mu \mathrm{L}$ of lysis buffer $(0.9 \%$ triton X100 in distilled water) per $100 \mu \mathrm{L}$ serum free media and left for $45 \mathrm{~min}$ at $37^{\circ} \mathrm{C}$. After centrifuging (13000 rpm, $5 \mathrm{~min}$ ), $50 \mu \mathrm{L}$ of cell lysate supernatant were mixed with $50 \mu \mathrm{L}$ of substrate mixture in a new microtiter plate and incubated for $6 \mathrm{~min}$ at room temperature. LDH content was determined by reading the absorbance at $490 \mathrm{~nm}$ using a multiwell plate reader (Fluostar Omega, BMG Labtech Ltd.). The amount of LDH detected after cell lysis indicated the number of cells that have survived to CNT exposure. The percentage cell survival is expressed as [LDH released from tested cells - Blank (media alone) / $\mathrm{LDH}$ released control cells- Blank (media alone)] $\times 100$. Each assay was performed at least 3 times, using 3 wells per conditions at each considered times.

Raman spectroscopy. A Thermo Scientific DXR Raman microscope, equipped with an Olympus microscope (100x objective lens) and a $633 \mathrm{~nm}$ LASER (1 mW of LASER power) was used to perform Raman spectroscopy. Collection of Raman spectra was performed as previously described ${ }^{14}$. 
Immunocytochemistry of microglial cells. Microglial cell cultures were prepared on poly-L-lysine coated plastic tissue-culture treated dishes (35 mm diam.). At the end of exposure, cells were fixed with pre-cooled methanol $\left(-20^{\circ} \mathrm{C}\right)$ for $10 \mathrm{~min}$, air-dried and then washed twice with PBS containing $0.1 \%$ triton (TPBS, $\mathrm{pH} 7.4$ ) before staining. Staining with primary antibody was performed after $1 \mathrm{~h}$ incubation (i.e. blocking) with $5 \%$ of normal goat serum in TPBS. Primary antibodies used were: mouse monoclonal anti-CD11b/c (1:200)(Ox42, Abcam) or mouse monoclonal anti-CD68 (ED1, Abcam, UK); both diluted in 2\% BSA in TPBS and incubated for $2 \mathrm{~h}$ at room temperature. The secondary antibody (goat anti-mouse Cy3 labelled) was used at the dilution of 1:250 in 2\% BSA in TPBS for $1 \mathrm{~h}$ at room temperature. After washing, cell preparations were mounted in appropriate medium containing anti-fading agent and DAPI (Vectashield, Vector laboratories LTD). Immunoreactivity was assessed on an inverted epifluorescence microscope (Carl Zeiss Axio Observer A1).

Inflammation markers (NO release) assess by Griess reagent assay. Inflammation reaction was based on the release of NO, a well-known biomarker of inflammation for microglial cells. As for the cytotoxicity assay, microglial cell cultures were generated in 24 well plates. Cells were then exposed to $10 \mu \mathrm{g} / \mathrm{mL}$ of the three different CNT suspensions or to CNT free medium. LPS (E. Coli, O26:B6, 200 $\mathrm{ng} / \mathrm{mL}$ ) was used as positive control for inflammation and was applied $24 \mathrm{~h}$ before performing the measurement on cell supernatants. At day 1, 7, 14 and 28 after CNT exposure, the amount of nitrite (stable breakdown products of NO) was measured using the Griess reagent system assay (Promega, UK) following the manufacturer's instructions. In brief, $50 \mu$ of each experimental sample was mixed with $50 \mu \mathrm{l}$ of the Sulfanilamide Solution. Following 8 min incubation, $50 \mu \mathrm{l}$ of the NED Solution were added to all wells for $8 \mathrm{~min}$ incubation before reading absorbance at $530 \mathrm{~nm}$. The amount of nitrite was determined by comparison to a nitrite standard reference curve, prepared and measured in parallel to each sample measurement.

Phagocytosis/internalisation ability assess by fluorescent polystyrene beads assay. To assess the internalisation ability of CNT-laden microglial cells, we used $0.50 \mu \mathrm{m}$ Fluoresbrite $®$ YellowGreen Microspheres (Polysiences, Inc.) and reduced the cell density of microglial cell cultures (1/2 of usual cell density when preparing mixed glia cell culture). No assay was performed at day 1 after the CNT exposure as some CNTs might still be present in the cell culture medium and compete with the beads for internalisation, despite precautious washings. Assays were therefore performed at day 7 of the recovery period. At this time point, $2 \mu \mathrm{L}$ of the initial beads suspension was diluted in $2 \mathrm{~mL}$ of complete cell culture medium. This bead diluted suspension was used to treat CNT-laden microglial cells prepared and cultured in $35 \mathrm{~mm}$ cell culture dishes. The phagocytosis of the fluorescently labelled beads was followed on an inverted epifluorescence microscope tuned on the FITC channel (Carl Zeiss Axio Observer A1) and recorded at 1, 2 and $8 \mathrm{~h}$ after bead treatment. Green fluorescence present in each picture was measured using ImageJ image processing and analysis software ( $\mathrm{NIH}, \mathrm{USA})$.

Migration ability assess by scratch assay. To assess the migration ability of CNT-laden microglial cells, we developed a migration assay based on the well-known wound-healing assay and using the formation of scratches at the bottom of the plastic cell culture support. Using reduced cell density of microglial cell cultures (1/2 of usual mixed glia cell density), we first exposed cells to $10 \mu \mathrm{g} / \mathrm{mL}$ of the different $f$-MWNT suspension for $24 \mathrm{~h}$ for loading purpose. As for the internalisation assay, no migration assay was performed at day 1 after CNT exposure because it was considered too soon after exposure and the presence of free CNTs on the cell culture surface might bias the migration assessment of CNT-laden microglial cells. On day 7, 14 and 28 of the recovery period, we generated straight scratches on the plastic surface of $35 \mathrm{~mm}$ cell culture dishes by gently drawing straight lines using a sterile plastic pipette tip. To allow a maximum number of cells to move towards the scratches, migration ability was assessed $72 \mathrm{~h}$ after generation of the scratches. Pictures were centred on the scratch and a ROI was drawn around the scratch to count the cells present in the ROI of each picture (ImageJ image processing and analysis software ( $\mathrm{NIH}, \mathrm{USA})$ ) as illustrated in supplementary information Figure $\mathbf{S 7 .}$ 
1

2

3

4

5

6

7

\section{Acknowledgments}

9 This work was supported by the European Commission, under the FP-7 Marie Curie actions (Career

10 Development Intra-European Fellowship, PIEF-GA-2010-276051, project NANONEUROHOP). AB wishes to

11

12

13

14

15

16

Statistics. Results are expressed as mean \pm SD. Statistical differences were analysed using the Student's $t$ test, and $p<0.05\left({ }^{*}\right)$ were considered as significantly different. Each assay was performed independently at least 3 times. One way ANOVA, Kruskal-Wallis test with Dunn's multiple comparison test was used to analyse the differences in the viability assay $p<0.05\left({ }^{*}\right)$ were considered as significantly different. thank the CNRS financial support from PICS (Project for International Scientific Cooperation). MP, as the recipient of the AXA Chair, is grateful to the AXA Research Fund for financial support. MP was also supported by the Spanish Ministry of Economy and Competitiveness MINECO (project CTQ2016-76721-R), by the University of Trieste and by Diputación Foral de Gipuzkoa program Red (101/16). 


\section{Figure Legends}

Figure 1: Characteristics of the different types of functionalised MWNTs. (a) Chemical structures of the different chemically functionalised MWNTs; (b) Table providing the abbreviations used in the manuscript, the length and the amount of amino groups for the different MWNTs.

Figure 2: Cytotoxic effects of different MWNTs on primary microglial cell cultures evaluated by modified LDH assay. Microglial cell cultures were exposed during $24 \mathrm{~h}$ to a unique dose of different MWNTs $(10 \mu \mathrm{g} / \mathrm{mL})$. Following different period of time after the exposure, the LDH assay was performed. No significant effect was observed compared to untreated cells or positive control (DMSO $10 \%$ ). One way ANOVA, Kruskal-Wallis test with Dunn's multiple comparison test was used to analyse the differences in the viability assay $p<0.05\left({ }^{*}\right)$ were considered as significantly different.

Figure 3: Imaging of primary microglial cells exposed to different functionalised MWNTs via optical microscopy and confirmation of CNT via Raman spectroscopy. Primary microglial cell cultures were exposed during $24 \mathrm{~h}$ to a unique dose of different MWNTs $(10 \mu \mathrm{g} / \mathrm{mL})$ and then leaved for different period of time before imaging. (a) Live imaging (phase contrast) of primary microglial cells at day 1 to 28 for the different exposure. LPS activation $(200 \mathrm{ng} / \mathrm{mL})$ was used as a control that induced a change in cell shape (cells flattened and spreaded). No significant difference in terms of shape or number of cells was observed between the non-treated cells and the cells exposed to MWNTs at any time of recovery after the initial exposure. (b) At the end of each desired time of recovery, primary microglial cells were fixed with $-20^{\circ} \mathrm{C}$ pre-cooled methanol and then air dried for at least one hour before further analysis. The Raman analysis of regions randomly selected within the cell boundaries was performed (as presented in Figure S5c). Intensities were normalised to the intensity of $G$ band $\left(I_{G}=1\right)$. For all MWNTs and for all time points considered, the typical Raman signature of MWNTs constituted of D, G and D' bands was obtained in regions which appeared black under bright-field microscopy. No Raman signature of CNTs was detected in white regions (nucleus and cell periphery). All scale bars shown are $100 \mu \mathrm{m}$.

Figure 4: Inflammation reaction assessed by a measurement of NO release using the Griess reagent assay. Microglial cell cultures were exposed during $24 \mathrm{~h}$ to a unique dose of different MWNTs $(10 \mu \mathrm{g} / \mathrm{mL})$. Following different period of time after the exposure, the Griess reagent system assay was performed. No significant effect was observed compared to untreated cells or positive control (LPS $200 \mathrm{ng} / \mathrm{mL}$ ). Only at day 1 after the initial CNT exposure, the NO release was higher than the untreated cells but minimal compared to the NO release induced by LPS stimulation.

Figure 5: Internalisation ability assessed by a fluorescently labelled microsphere assay. Microglial cell cultures were exposed during $24 \mathrm{~h}$ to a unique dose of different MWNTs (10 $\mu \mathrm{g} / \mathrm{mL})$. On day 7 after this initial exposure, microglial cells were treated with fluorescently labelled microspheres $(0.5 \mu \mathrm{m})$. The internalisation of the fluorescent microspheres was recorded at $2 \mathrm{~h}(\mathrm{a})$ and $8 \mathrm{~h}$ (b) after the treatment. For the LPS control, untreated cells were exposed to LPS $(200 \mathrm{ng} / \mathrm{mL})$ $24 \mathrm{~h}$ before the microsphere treatment in order to separate LPS stimulation and microsphere exposure, as for the MWNT exposure. A quantitative measurement of the fluorescence obtained in each pictures was analysed via ImageJ and is presented in (c). For $8 \mathrm{~h}$, results presented have been divided by a factor 10 for all conditions. After 1 and $8 \mathrm{~h}$, no significant internalisation was observed compared to untreated or LPS stimulated cells. At $2 \mathrm{~h}$ following microsphere exposure, LPS stimulated cells internalised more microsphere than untreated cells. All scale bars shown are $100 \mu \mathrm{m}$.

Figure 6: Migration ability assessed by a scratch assay. Microglial cell cultures were exposed during $24 \mathrm{~h}$ to a unique dose of different MWNTs $(10 \mu \mathrm{g} / \mathrm{mL})$. On day 7,14 and 28 days after this initial exposure, the plastic surface of microglial cell culture was submitted to scratches. Seventy two hours after the scratch, the amount of cells that have migrated toward the scratch was imaged and 
counted using ImageJ. For the LPS control, untreated cells were exposed to LPS ( $200 \mathrm{ng} / \mathrm{mL}) 24 \mathrm{~h}$ before the formation of scratch on the plastic surface. The migration is presented as the percentage compared to untreated cells. LPS treatment was founded to inhibit the migration of microglial cells. The exposure to ox-MWNTs or ox-MWNT-NH ${ }_{3}{ }^{+}$were found to significantly stimulate microglial cell migration at both 14 and 28 days, with ox-MWNTs having a higher stimulation than ox-MWNT-NH ${ }_{3}^{+}$. In contrast, MWNT- $\mathrm{NH}_{3}{ }^{+}$showed a limited effect on the microglial cell migration ability compared to untreated cells.

\section{Supplementary Figure Legends}

Figure S1: Stability of $f$-MWNT suspension in different media assessed by UV-Vis spectrophotometry. Stability of the three $f$-MWNTs $(10 \mu \mathrm{g} / \mathrm{mL})$ suspended in $5 \%$ dextrose water solution (first column), in cell culture medium (DMEM:F12) supplemented with $12 \%$ FBS (second column) and in cell culture medium without FBS (third column) are presented at $0 \mathrm{~h}$ (red spectra) and $24 \mathrm{~h}$ (blue spectra). Absorbance spectra for the suspension media are also displayed (bottom raw). Each $f$-MWNT presented specific spectra in each medium. All three $f$-MWNTs showed no difference in absorbance between $0 \mathrm{~h}$ (blue spectra) and $24 \mathrm{~h}$ (red spectra) when suspended in $5 \%$ dextrose or in cell culture medium with $12 \%$ FBS, red spectra overlapped with blue spectra. In contrast, a clear decrease in absorbance between $0 \mathrm{~h}$ and $24 \mathrm{~h}$ was observed for all three $f$-MWNTs when suspended in cell culture medium without FBS. While the blue spectra were specific to each MWNT tested, a similar red spectra below the blue one was observed at $24 \mathrm{~h}$ for all three $f$-MWNTs, suggesting instability of suspensions and sedimentation of the three $f$-MWNTs when suspended in this medium.

Figure S2: Optical microscopy of live primary microglial cells after exposure to $f$-MWNTs. Primary microglia cell cultures were imaged at 1 (a), 7 (b), 14 (c) or 28 (d) days after a $24 \mathrm{~h}$ treatment with different $f$-MWNTs $(10 \mu \mathrm{g} / \mathrm{mL}$ or $0 \mu \mathrm{g} / \mathrm{mL}$ ). The same field of view is displayed after imaging under either phase contrast or bright field illumination. Bright field was used to highlight black regions in cells indicating the presence of carbon nanotubes. For all microglial cell cultures (exposed and nonexposed), cells with either elongated, spread or round shapes were found. All scale bars shown are $100 \mu \mathrm{m}$.

Figure S3: Optical microscopy of live primary microglia exposed to $f$-MWNTs (higher magnification). Primary microglia cell cultures were imaged at 1 (a), 14 (b) or 28 (c) days after a $24 \mathrm{~h}$ treatment with different $f$-MWNTs $(10 \mu \mathrm{g} / \mathrm{mL})$ using a $20 \mathrm{x}$ objective. Higher magnification at $40 \mathrm{x}$ are provided for $\mathrm{MWNT}-\mathrm{NH}_{3}{ }^{+}$after 7 days (d). The same field of view is displayed after imaging under either phase contrast or bright field illumination. Bright field was used to highlight black regions in cells indicating the presence of carbon nanotubes. All scale bars shown are $100 \mu \mathrm{m}$.

Figure S4: Immunocytochemistry of $\boldsymbol{f}$-MWNTs laden microglia. Microglial cells cultures were fixed with pre-cooled methanol, washed and immunostained with mouse anti-rat CD11b/c (microglial cell marker) antibodies in combination with secondary anti-mouse Cy3 antibodies or with mouse anti-rat CD68 (macrophage marker) antibodies in combination with secondary anti-mouse Cy3 antibodies. (a) Merged images of DAPI stain with CD11b/c or CD68 immunoreactivities for the different conditions. (b) Close up on $f$-MWNT laden microglial cells for the 3 different types of MWNTs tested highlighting the vesicular pattern of the MWNT loading inside the cytoplasm of microglial cells. All scale bars shown are $100 \mu \mathrm{m}$.

Figure S5: Raman spectroscopy of starting materials before cell exposure and imaging of fixed cells before Raman analysis. (a) Raman spectroscopy of the three different materials used before cell exposure was performed by deposing a drop of the starting $5 \%$ dextrose dispersion of MWNTs ( 1 
$1 \mu \mathrm{g} \mathrm{MWNT} / \mathrm{mL}$ ) on a glass slide. (b) Representative pictures of cells exposed to $\mathrm{MWNT}-\mathrm{NH}_{3}{ }^{+}$showing

2 the typical distribution of nanotubes around the nucleus and a granular accumulation pattern

3 suggesting vesicular accumulation, both in phase contrast and bright-field mode. (c) Representative

4 pictures of untreated cells or cells exposed to $\mathrm{MWNT}^{-\mathrm{NH}_{3}}{ }^{+}$in bright-field mode at different levels of

5 magnification. Also presented is a typical map for point and shout Raman analysis.

Figure S6: Internalisation ability assessed by a fluorescently labelled microsphere assay.

Microglial cell cultures were exposed during $24 \mathrm{~h}$ to a unique dose of different MWNTs (10 $\mu \mathrm{g} / \mathrm{mL})$. On day 7 after this initial exposure, microglial cells were treated with fluorescently labelled microspheres $(0.5 \mu \mathrm{m})$. The internalisation of the fluorescent microspheres was recorded at $1 \mathrm{~h}$ after the treatment. For the LPS control, untreated cells were exposed to LPS $(200 \mathrm{ng} / \mathrm{mL}) 24 \mathrm{~h}$ before the microsphere treatment in order to separate LPS stimulation and microsphere exposure, as for the MWNTs exposure. A quantitative measurement of the fluorescence obtained in each pictures was analysed via Image $\mathrm{J}$ and is presented in Figure 3c. All scale bars shown are $100 \mu \mathrm{m}$.

Figure S7: Migration ability assessed by a scratch assay. Microglial cell cultures were exposed during $24 \mathrm{~h}$ to a unique dose of different MWNTs $(10 \mu \mathrm{g} / \mathrm{mL})$. On day 7,14 and 28 days after this initial exposure, the plastic surface of cell culture was submitted to scratches (see schemes). After the scratch, cells that have migrated towards the scratch was imaged (representative pictures, $72 \mathrm{~h}$ after the scratch) and counted using ImageJ in the ROI highlighted in yellow. For the LPS control, untreated cells were exposed to LPS $(200 \mathrm{ng} / \mathrm{mL}) 24 \mathrm{~h}$ before the formation of scratch on the plastic surface. All scale bars shown are $100 \mu \mathrm{m}$. 


\section{References}

1. P. Blasi, S. Giovagnoli, A. Schoubben, M. Ricci and C. Rossi, Adv Drug Deliv Rev, 2007, 59, 454-477.

2. T. Patel, J. Zhou, J. M. Piepmeier and W. M. Saltzman, Adv Drug Deliv Rev, 2012, 64, 701-705.

3. S. B. Pehlivan, Pharm Res, 2013, 30, 2499-2511.

4. J. T. Wang and K. T. Al-Jamal, Nanomedicine (Lond), 2015, 10, 2639-2642.

5. K. Kostarelos, L. Lacerda, G. Pastorin, W. Wu, S. Wieckowski, J. Luangsivilay, S. Godefroy, D. Pantarotto, J. P. Briand, S. Muller, M. Prato and A. Bianco, Nat Nanotechnol, 2007, 2, 108-113.

6. Z. Yang, Y. Zhang, Y. Yang, L. Sun, D. Han, H. Li and C. Wang, Nanomedicine-Uk, 2010, 6, 427-441.

7. K. T. Al-Jamal, L. Gherardini, G. Bardi, A. Nunes, C. Guo, C. Bussy, M. A. Herrero, A. Bianco, M. Prato, K. Kostarelos and T. Pizzorusso, Proc Natl Acad Sci U S A, 2011, 108, 10952-10957.

8. H. J. Lee, J. Park, O. J. Yoon, H. W. Kim, D. Y. Lee, D. H. Kim, W. B. Lee, N. E. Lee, J. V. Bonventre and S. S. Kim, Nature Nanotechnology, 2011, 6, 120-124.

9. M. K. Gottipati, E. Bekyarova, R. C. Haddon and V. Parpura, Amino acids, 2015, 47, 1379-1388.

10. G. Tosi, A. Vilella, R. Chhabra, M. J. Schmeisser, T. M. Boeckers, B. Ruozi, M. A. Vandelli, F. Forni, M. Zoli and A. M. Grabrucker, J Control Release, 2014, 177, 96107.

11. G. Bardi, A. Nunes, L. Gherardini, K. Bates, K. T. Al-Jamal, C. Gaillard, M. Prato, A. Bianco, T. Pizzorusso and K. Kostarelos, PLoS One, 2013, 8, e80964.

12. A. Nunes, C. Bussy, L. Gherardini, M. Meneghetti, M. A. Herrero, A. Bianco, M. Prato, T. Pizzorusso, K. T. Al-Jamal and K. Kostarelos, Nanomedicine (Lond), 2012, 7, 1485-1494.

13. C. Bussy, K. T. Al-Jamal, J. Boczkowski, S. Lanone, M. Prato, A. Bianco and K. Kostarelos, ACS Nano, 2015, 9, 7815-7830.

14. C. Bussy, C. Hadad, M. Prato, A. Bianco and K. Kostarelos, Nanoscale, 2016, 8, 590601.

15. J. Russier, L. Oudjedi, M. Piponnier, C. Bussy, M. Prato, K. Kostarelos, B. Lounis, A. Bianco and L. Cognet, Nanoscale, 2017.

16. A. E. Goode, D. A. Gonzalez Carter, M. Motskin, I. S. Pienaar, S. Chen, S. Hu, P. Ruenraroengsak, M. P. Ryan, M. S. Shaffer, D. T. Dexter and A. E. Porter, Biomaterials, 2015, 70, 57-70.

17. L. C. Davies, S. J. Jenkins, J. E. Allen and P. R. Taylor, Nat Immunol, 2013, 14, 986995.

18. J. C. Villegas, L. Alvarez-Montes, L. Rodriguez-Fernandez, J. Gonzalez, R. Valiente and M. L. Fanarraga, Adv Healthc Mater, 2014, 3, 424-432.

19. N. V. Konduru, Y. Y. Tyurina, W. Feng, L. V. Basova, N. A. Belikova, H. Bayir, K. Clark, M. Rubin, D. Stolz, H. Vallhov, A. Scheynius, E. Witasp, B. Fadeel, P. D. Kichambare, A. Star, E. R. Kisin, A. R. Murray, A. A. Shvedova and V. E. Kagan, Plos One, 2009, 4, e4398.

20. C. Bussy, M. Pinault, J. Cambedouzou, M. J. Landry, P. Jegou, M. Mayne-L'hermite, P. Launois, J. Boczkowski and S. Lanone, Part Fibre Toxicol, 2012, 9, 46.

21. J. T. Wang, N. Rubio, H. Kafa, E. Venturelli, C. Fabbro, C. Menard-Moyon, T. Da Ros, J. K. Sosabowski, A. D. Lawson, M. K. Robinson, M. Prato, A. Bianco, F. Festy, J. E. Preston, K. Kostarelos and K. T. Al-Jamal, J Control Release, 2016, 224, 22-32. 
22. H. Ali-Boucetta, K. T. Al-Jamal, D. McCarthy, M. Prato, A. Bianco and K.

2

Kostarelos, Chem Commun (Camb), 2008, 459-461.

23. R. Singh, D. Pantarotto, D. McCarthy, O. Chaloin, J. Hoebeke, C. D. Partidos, J. P. Briand, M. Prato, A. Bianco and K. Kostarelos, J Am Chem Soc, 2005, 127, 43884396.

24. A. Servant, I. Jacobs, C. Bussy, C. Fabbro, T. da Ros, E. Pach, B. Ballesteros, M. Prato, K. Nicolay and K. Kostarelos, Carbon, 2016, 97, 126-133.

25. S. P. Li, W. Wu, S. Campidelli, V. Sarnatskaia, M. Prato, A. Tridon, A. Nikolaev, V. Nikolaev, A. Bianco and E. Snezhkova, Carbon, 2008, 46, 1091-1095.

26. C. Gaillard, G. Cellot, S. P. Li, F. M. Toma, H. Dumortier, G. Spalluto, B. Cacciari, M. Prato, L. Ballerini and A. Bianco, Advanced Materials, 2009, 21, 2903-+.

27. V. Georgakilas, K. Kordatos, M. Prato, D. M. Guldi, M. Holzinger and A. Hirsch, Journal of the American Chemical Society, 2002, 124, 760-761.

28. V. Georgakilas, N. Tagmatarchis, D. Pantarotto, A. Bianco, J. P. Briand and M. Prato, Chem Commun (Camb), 2002, 3050-3051.

29. P. Wick, P. Manser, L. K. Limbach, U. Dettlaff-Weglikowska, F. Krumeich, S. Roth, W. J. Stark and A. Bruinink, Toxicol Lett, 2007, 168, 121-131.

30. L. Dong, C. M. Witkowski, M. M. Craig, M. M. Greenwade and K. L. Joseph, Nanoscale Res Lett, 2009, 4, 1517-1523.

31. E. A. Salegio, H. Streeter, N. Dube, P. Hadaczek, L. Samaranch, A. P. Kells, W. San Sebastian, Y. Zhai, J. Bringas, T. Xu, J. Forsayeth and K. S. Bankiewicz, Frontiers in neuroanatomy, 2014, 8, 9.

32. H. Ali-Boucetta, K. T. Al-Jamal, K. H. Muller, S. Li, A. E. Porter, A. Eddaoudi, M. Prato, A. Bianco and K. Kostarelos, Small, 2011, 7, 3230-3238.

33. S. Ganter, H. Northoff, D. Mannel and P. J. Gebickeharter, J Neurosci Res, 1992, 33, 218-230.

34. M. P. Ramprasad, V. Terpstra, N. Kondratenko, O. Quehenberger and D. Steinberg, Proc Natl Acad Sci U S A, 1996, 93, 14833-14838.

35. M. S. Dresselhaus, G. Dresselhaus, R. Saito and A. Jorio, Physics Reports, 2005, 409, 47-99.

36. M. S. Dresselhaus, A. Jorio, M. Hofmann, G. Dresselhaus and R. Saito, Nano Lett, 2010, 10, 751-758.

37. K. Saijo and C. K. Glass, Nature reviews. Immunology, 2011, 11, 775-787.

38. T. Tajima, T. Murata, K. Aritake, Y. Urade, H. Hirai, M. Nakamura, H. Ozaki and M. Hori, J Pharmacol Exp Ther, 2008, 326, 493-501.

39. H. Scheiblich, F. Roloff, V. Singh, M. Stangel, M. Stern and G. Bicker, Brain Res, 2014, 1564, 9-21.

40. N. Luo, J. K. Weber, S. Wang, B. Luan, H. Yue, X. Xi, J. Du, Z. Yang, W. Wei, R. Zhou and G. Ma, Nat Commun, 2017, 8, 14537.

41. B. Kateb, M. Van Handel, L. Zhang, M. J. Bronikowski, H. Manohara and B. Badie, Neuroimage, 2007, 37 Suppl 1, S9-17.

42. L. Xie, H. Kang, Q. Xu, M. J. Chen, Y. Liao, M. Thiyagarajan, J. O'Donnell, D. J. Christensen, C. Nicholson, J. J. Iliff, T. Takano, R. Deane and M. Nedergaard, Science, 2013, 342, 373-377.

43. J. J. Iliff, M. Wang, Y. Liao, B. A. Plogg, W. Peng, G. A. Gundersen, H. Benveniste, G. E. Vates, R. Deane, S. A. Goldman, E. A. Nagelhus and M. Nedergaard, Science translational medicine, 2012, 4, 147ra111.

44. L. Rodriguez-Fernandez, R. Valiente, J. Gonzalez, J. C. Villegas and M. L. Fanarraga, ACS Nano, 2012, 6, 6614-6625. 
45. S. Lanone, P. Andujar, A. Kermanizadeh and J. Boczkowski, Adv Drug Deliv Rev, 2013, 65, 2063-2069.

46. H. Nagai, Y. Okazaki, S. H. Chew, N. Misawa, Y. Yamashita, S. Akatsuka, T. Ishihara, K. Yamashita, Y. Yoshikawa, H. Yasui, L. Jiang, H. Ohara, T. Takahashi, G. Ichihara, K. Kostarelos, Y. Miyata, H. Shinohara and S. Toyokuni, Proc Natl Acad Sci U S A, 2011, 108, E1330-1338.

47. C. A. Poland, R. Duffin, I. Kinloch, A. Maynard, W. A. Wallace, A. Seaton, V. Stone, S. Brown, W. Macnee and K. Donaldson, Nat Nanotechnol, 2008, 3, 423-428.

48. C. Muhlfeld, C. A. Poland, R. Duffin, C. Brandenberger, F. A. Murphy, B. RothenRutishauser, P. Gehr and K. Donaldson, Nanotoxicology, 2012, 6, 867-879.

49. J. Russier, C. Menard-Moyon, E. Venturelli, E. Gravel, G. Marcolongo, M. Meneghetti, E. Doris and A. Bianco, Nanoscale, 2011, 3, 893-896.

50. J. Saura, J. M. Tusell and J. Serratosa, Glia, 2003, 44, 183-189. 
a

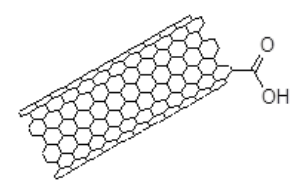

ox-MWNT

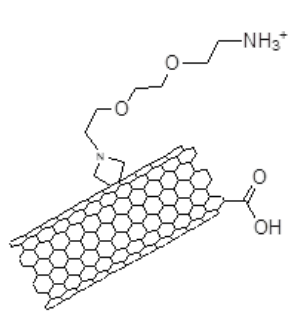

ox-MWNT- $\mathrm{NH}_{3}{ }^{+}$

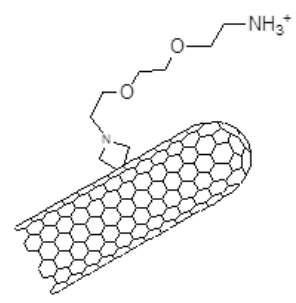

MWNT-NH ${ }_{3}^{+}$

b

Short name

Nature of MWCNT

Amount of

amino groups

(Kaiser test)

carboxylated

carboxylated and aminated (cycloaddition)

aminated (cycloaddition)

ox-MWNT
ox-MWNT- $\mathrm{NH}_{3}^{+}$
MWNT- $\mathrm{NH}_{3}^{+}$

-

$-$

$170 \mu \mathrm{mol} / \mathrm{g}$

$84 \mu \mathrm{mol} / \mathrm{g}$
Length

(TEM)
$200-300 \mathrm{~nm}$

$200-300 \mathrm{~nm}$

$0.5-2 \mu \mathrm{m}$ 


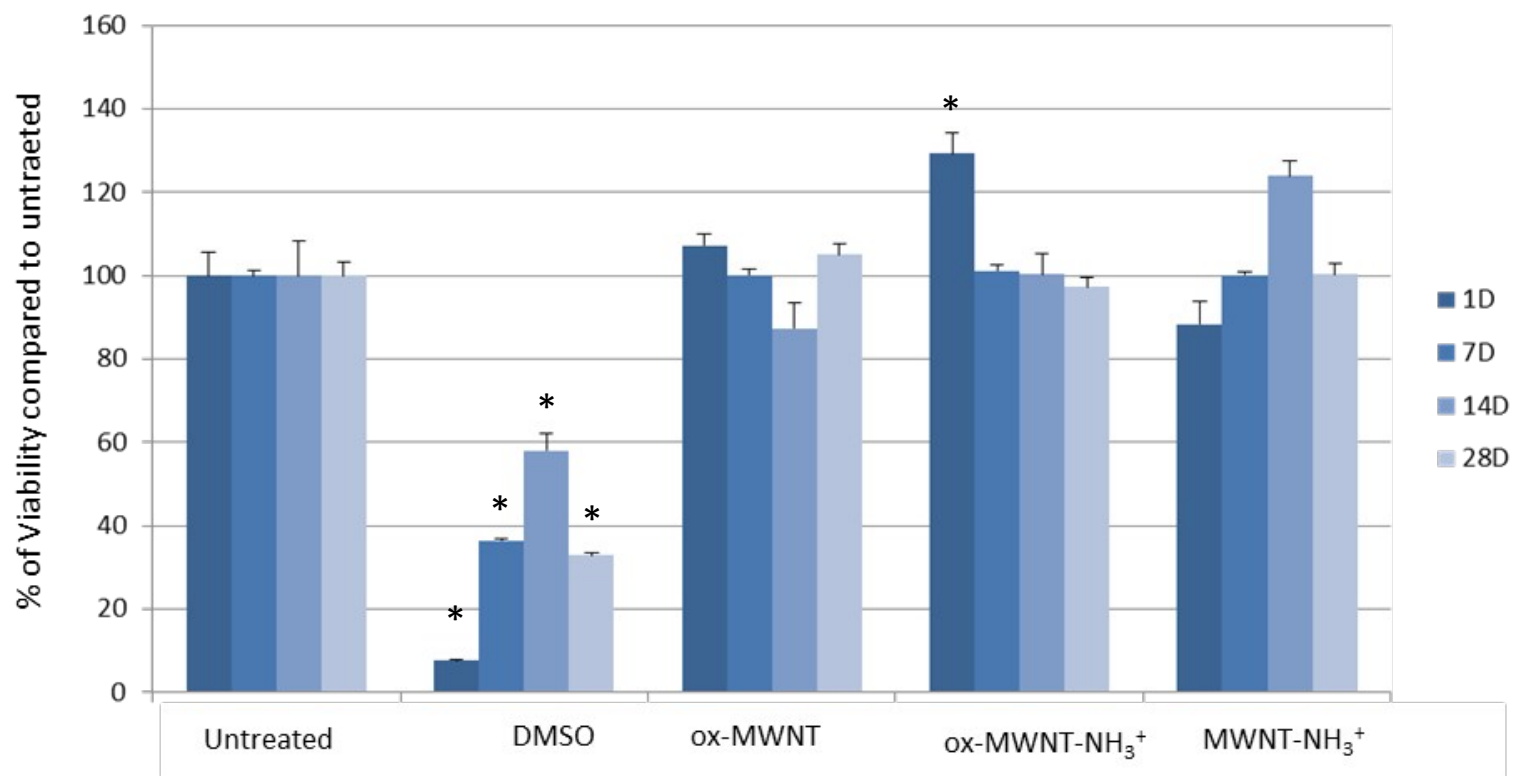




\section{Page 25 of 28}

Nanoscale Horizons

a
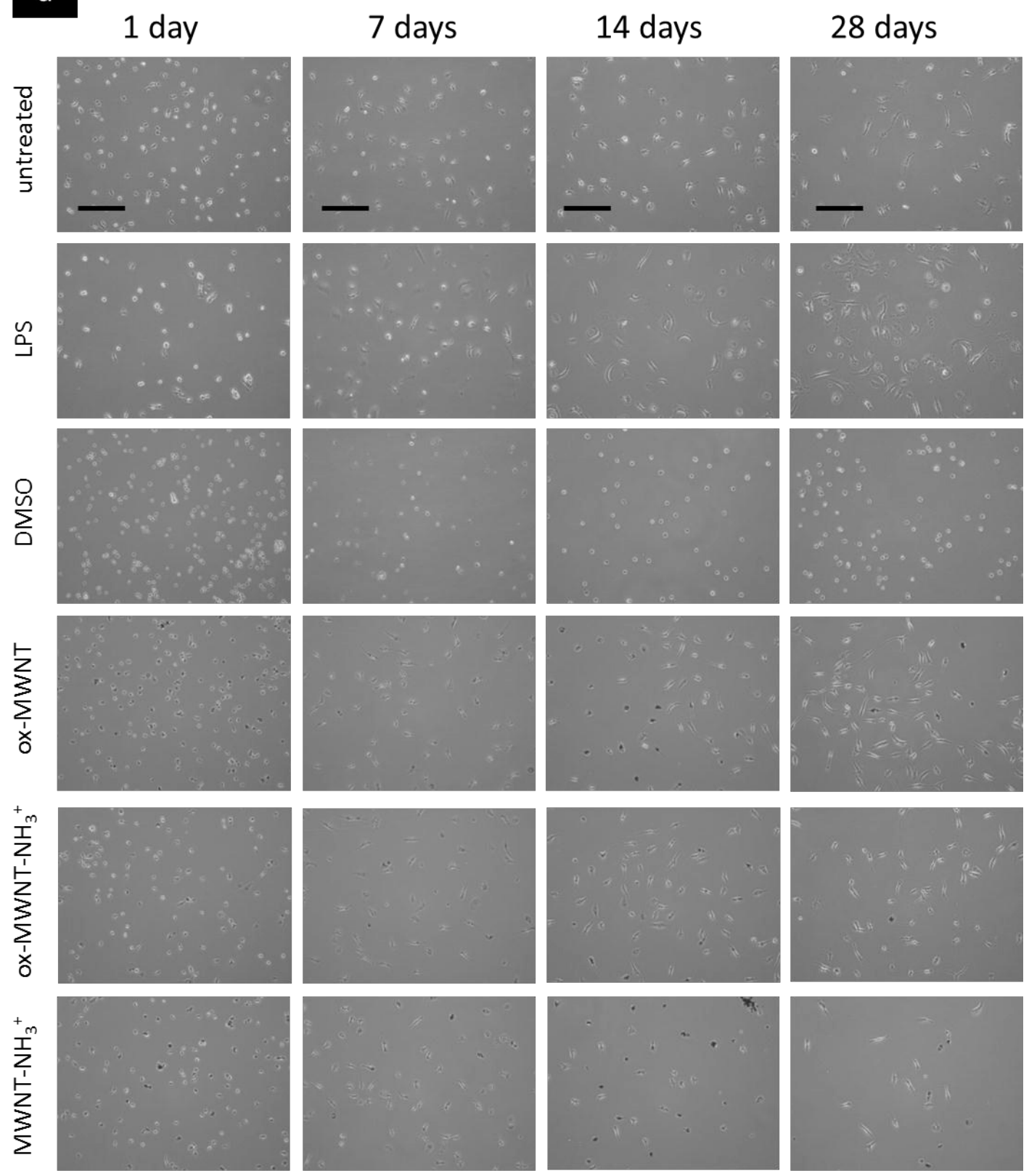

\section{b}
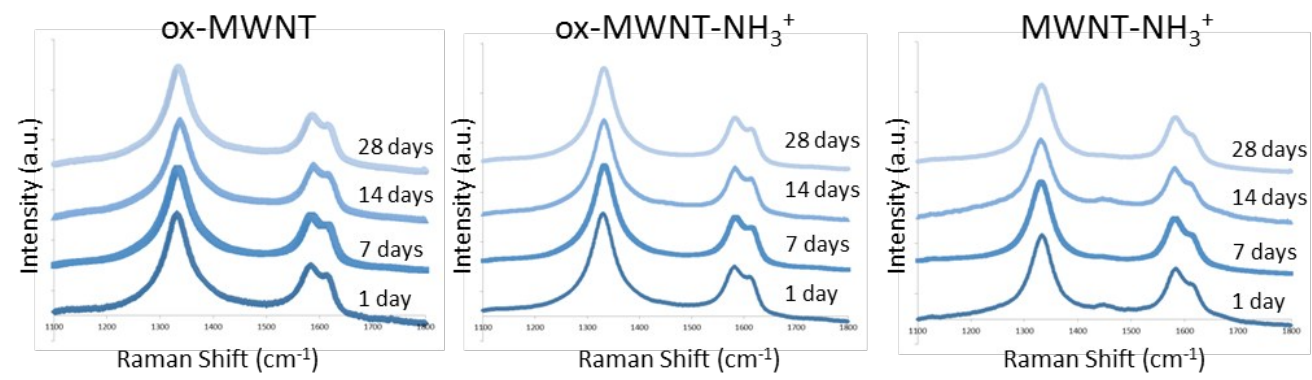

FIGURE 3 


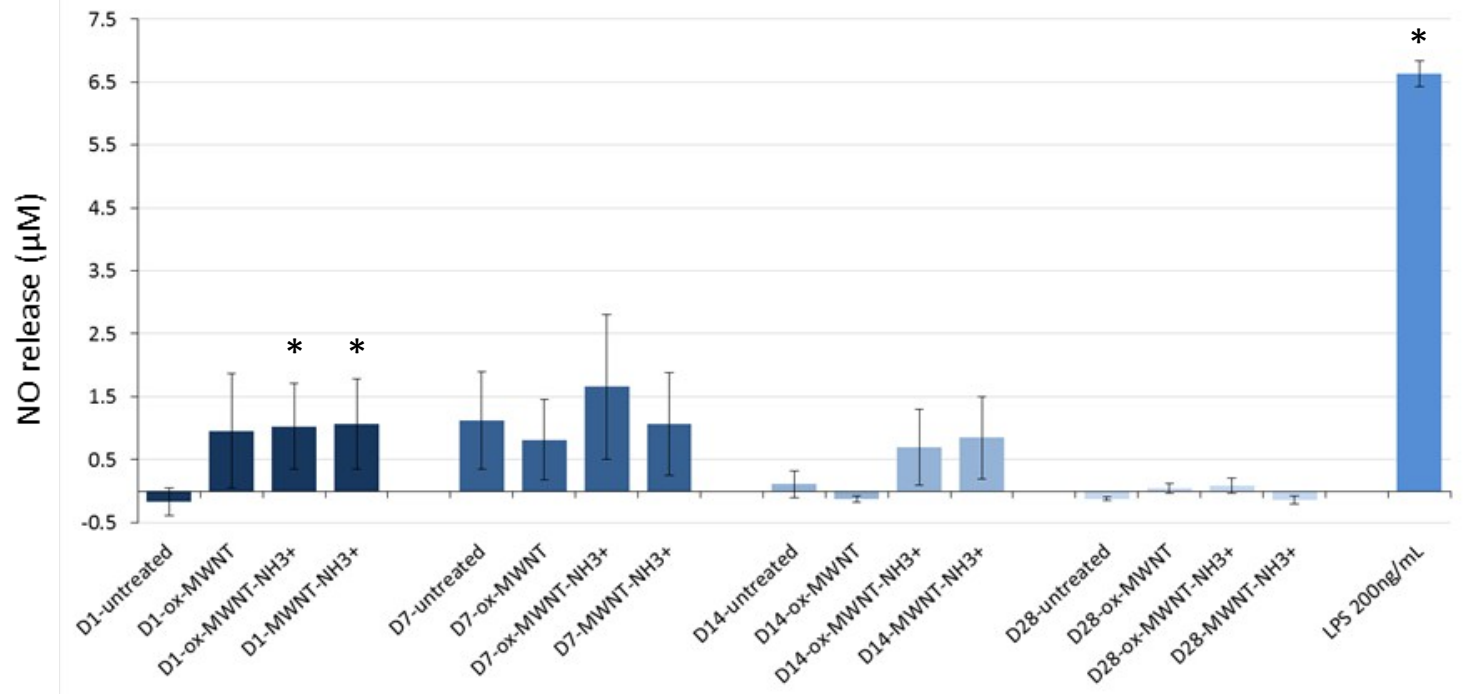

FIGURE 4 


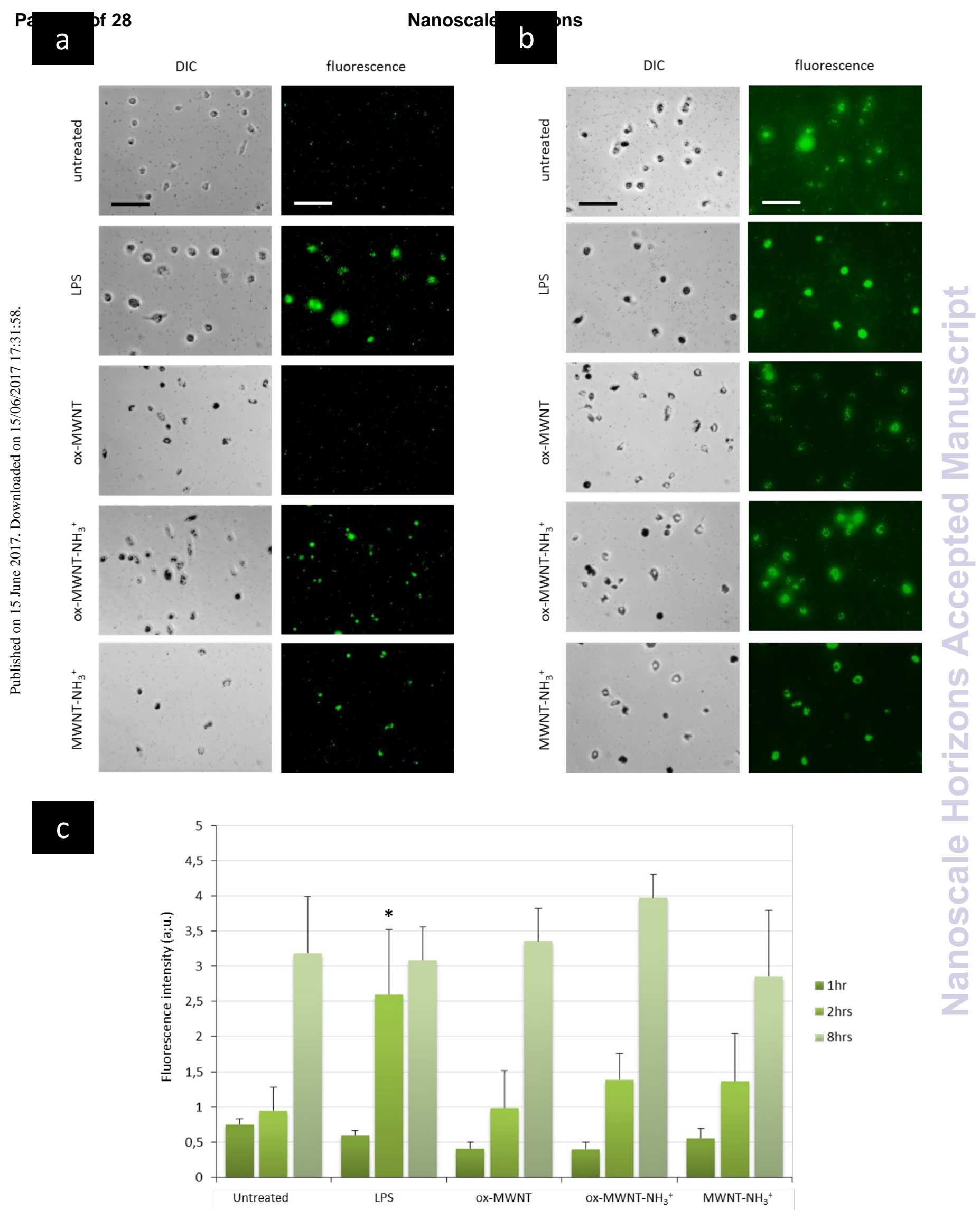

FIGURE 5 


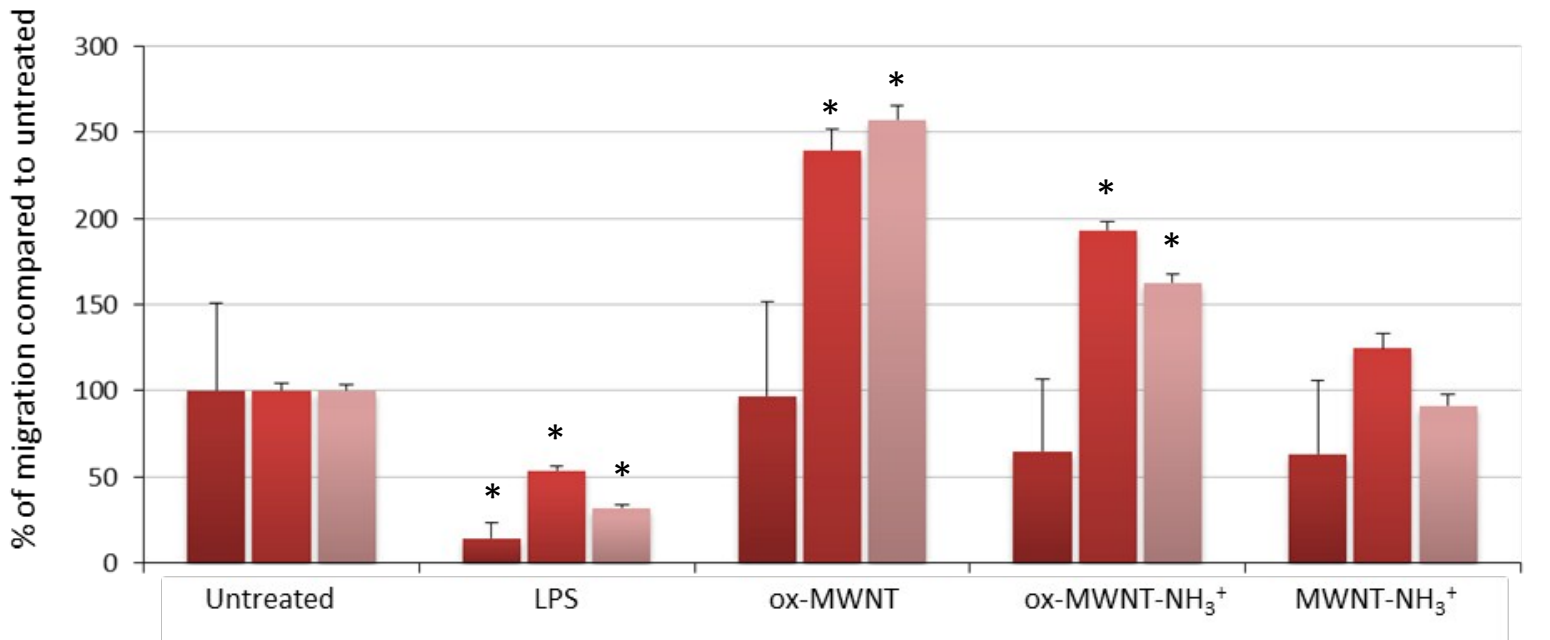

- 7D

- $14 \mathrm{D}$

= $28 \mathrm{D}$ 